\section{Inefficient Transmission of Citrus Tristeza Virus from Grapefruit by Single Brown Citrus Aphids}

\author{
Youjian Lin \\ Department of Plant Protection, Fujian Agricultural University, Fuzhou, \\ Fujian 350002 China
}

R.H. Brlansky

Citrus Research and Education Center, University of Florida, Lake Alfred, FL 33850-2299

Charles A. Powell

Indian River Research and Education Center, University of Florida, Fort Pierce, FL 34945-3138

Additional index words. isolates, source plant, 'Mexican' lime, aphid morphological stages, ELISA, Toxoptera citricida

\begin{abstract}
Six severe and six mild Florida isolates of citrus tristeza virus (CTV) were used to evaluate the transmission efficiency of the virus from grapefruit seedlings by single brown citrus aphids (Toxoptera citricida Kirkaldy) (BrCA) from colonies initiated by aphids obtained from citrus groves in Fort Pierce, Fla. The transmission rate to 2120 receptor plants ['Mexican' lime (Citrus aurantifolia)] from grapefruit by single BrCA was $1.5 \%$. Single BrCA transmitted four of the six severe isolates and three of the six mild isolates of CTV. The average transmission rate of severe isolates was $1.8 \%$, higher than that $(0.9 \%)$ of mild isolates. Severe isolate $\mathrm{Y}-7$ had the highest transmission rate among six severe isolates, $3.6 \%$. Mild isolate $\mathrm{Y}-23$ had the highest transmission rate among the mild isolates, 3.0\%. The transmission rates of CTV by alatae, apterae, or nymphs of BrCA were $1.5 \%, 1.5 \%$, and $1.0 \%$, respectively. The results suggested that $\mathrm{BrCA}$ is an inefficient vector of $\mathrm{CTV}$ when the source plant is grapefruit.
\end{abstract}

The brown citrus aphid (Toxoptera citricida Kirkaldy)(BrCA)(synonyms: Aphis citricidus, A. aeglis, A. nigricans, A. tavarresi, Myzus citricidus, and Paratoxoptera argentiniensis) has been widely considered the most effective vector of citrus tristeza virus (CTV) since it was first demonstrated that $\mathrm{BrCA}$ had the ability to transmit CTV (Abate, 1988; Cambra et al., 1981; Essig, 1949). Studies carried out by Costa et al. (1951), Nickel et al. (1984), Yokomi and Damsteegt (1990), Kano and Koizumi (1991), and Broadbent et al. (1996) in different countries showed that the transmission rates of CTV by BrCA varied. The transmission rates of CTV by single and multiple (3-100) BrCA ranged from 0\% to $66.6 \%$ and from $0 \%$ to $91.6 \%$, respectively (Broadbent et al., 1996; Costa and Grant, 1951; Lastra et al., 1992; Nickel et al., 1984; Yokomi et al., 1994). The factors affecting the transmission efficiency of CTV by BrCA included the isolate of CTV, source plant of the virus and the morphological stage of the aphid (Abate, 1988; Broadbent et al., 1996; Costa and Grant, 1951;

Received for publication 13 July 2001. Accepted for publication 24 Dec. 2002. This project was funded by USDA cooperative agreement 58-6617-4-018. Florida Agricultural Experiment Station Journal Series R-066-91 We thank S.M. Garnsey for providing CTV PCA1212, Phyllis A. Rundell, R.R. Bullock and the staff at the Indian River Research and Education Center for their assistance.
Rocha-Pena et al., 1995; Sharma, 1989; Yokomi and Damsteegt, 1990; Yokomi et al., 1994; Yokomi and Garnsey, 1987). The effects of sweet orange [Citrus sinensis (L.)] and 'Mexican' lime [C. aurantifolia (Christm.)] on CTV transmission efficiency by BrCA were revealed from the studies carried out by Costa et al. (1951), Yokomi and Damsteegt (1990) and Broadbent et al. (1996). The transmission rates of $\mathrm{CTV}$ by single $\mathrm{BrCA}$ from sweet orange were $0 \%$ to $55 \%$ (Costa and Grant, 1951; Yokomi et al., 1994), and the transmission rates of CTV by single BrCA from ' $\mathrm{Mexi}$ can' lime were $16.6 \%$ to $66.6 \%$ (Nickel et al., 1984). When compared to the results of CTV transmission experiments with other aphids, the transmission efficiency of CTV from sweet orange and 'Mexican' lime by $\mathrm{BrCA}$ was apparently much higher than that by other aphids. It was suggested that $\mathrm{BrCA}$ is the most effective vector of CTV from sweet orange and 'Mexican' lime plants (Abate, 1988; Broadbent et al., 1996; Michand, 1998; RochaPena et al., 1995; Roistacher and Bar-Jospeh, 1987; Yokomi et al., 1989; Yokomi and Garnsey, 1987; Yokomi et al., 1994). The aphid transmission rates of CTV by cotton aphid (Aphis gossypii Glover) varied with the virus source plants and with the severity of CTV isolate (Bar-Joseph and Loebenstein, 1973; Bar-Joseph et al., 1977). Even more, the results showed that the transmission rate of CTV from grapefruit (C. paradisi) or lemon
(C. limon) by cotton aphid was much lower than that from other source plants (Bar-Joseph et al., 1973, 1977). Otherwise, the transmission efficiency of CTV from grapefruit and other variety source plants by $\mathrm{BrCA}$ is still unknown.

BrCA was first detected in Florida in early Nov. 1995 in Metropolitan Dade and Broward counties. With the northward movement of $\mathrm{BrCA}$, the grapefruit industry in Florida may be at increased risk $[\approx 48 \%$ of the grapefruit industry in Florida is still on sour orange rootstock, the most sensitive rootstock of citrus to CTV (Ed Stover, unpublished data)]. Grapefruit is an important Florida fruit crop, especially in the Indian River region (St. Lucie County and Indian River County). The production of grapefruit in the Indian River region is $\approx 60 \%$ of the state's total production. Florida produces $\approx 80 \%$ of grapefruit (total production is $\approx 2.6$ million tons per year) in the United States (Jackson, 1991). The objective of this research was to evaluate the ability of BrCA to transmit CTV from grapefruit trees.

\section{Materials and Methods}

Virus isolates and source plants. Six CTV severe isolates (T-36, T-3, Y-3, Y-6, Y-7, and MG-3) and six mild isolates (T-30, T-26, T-4, $\mathrm{Y}-5, \mathrm{Y}-23$, and $\mathrm{Y}-26$ ), collected from Florida field trees by budding or aphid transmission, were used to evaluate the transmission efficiency of CTV from grapefruit seedlings by single BrCA. The severity of the isolates was classified based on their reactions with CTV monoclonal antibodies (MAb) 17G11 and MCA13 in enzyme-linked immunosorbent assay (ELISA). Isolates that reacted with 17G11 and MCA13 were considered severe, decline-producing isolates; the ones that reacted with only $17 \mathrm{G} 11$ were considered mild, non-decline producing isolates (Table 1). Isolates Y-3, Y-7, Y-23, and Y-26 were collected from cross-protected grapefruit trees that were first inoculated with a mild isolate and then with a severe field isolate in Fort Pierce, Fla. Isolates Y-5 and Y-6 were field isolates collected directly from grapefruit groves in Fort Pierce, Fla. T-36, T-3, T-30, T-26, and T-4 were originally obtained from Florida citrus groves by aphid transmission many years ago and have been maintained in the greenhouse. Isolate MG-3 was a man-made isolate obtained by budding isolates T-36, T-30, T-26, $\mathrm{T}-4$, and $\mathrm{T}-3$ into a single plant. Isolates $\mathrm{T}-36$ and $\mathrm{T}-3$ cause severe vein clearing, stunting and stem pitting on 'Mexican lime', mild seedling yellow symptoms on 'Eureka' lemon and sour orange seedlings, and quick decline of sweet orange trees on sour orange rootstock. Isolates T-30, T-26, and T-4 caused mild to moderate symptoms on 'Mexican' lime, Eureka lemon, and sour orange seedlings and no symptoms on sweet orange trees on sour orange rootstock. The biological characteristics of isolates Y-3, Y-7, Y-5, Y-6, $\mathrm{Y}-23, \mathrm{Y}-26$, and MG-3 were not determined. All isolates used in this experiment were grafted into 'Duncan' grapefruit seedlings. Infection of the 'Duncan' grapefruit seedlings with dif- 
ferent isolates of CTV was confirmed by ELISA with CTV MAb 17G11, and these virus source plants were maintained in an insect-protected green house at the Indian River Research and Education Center, Fort Pierce, Fla.

Receptor indicator plants. 'Mexican' lime seedlings were used as the receptor indicator plants in this experiment. Seeds of 'Mexican' lime were sown in trays filled with custom soil mix (Conrad Fafard, Apopka, Fla.), and grown under greenhouse conditions for 6-12 mo. The seedlings were then transplanted into plastic pots containing the above soil mix, one to three plants per pot. Seedlings with new flush were used as receptor indicator plants for single BrCA transmission of CTV. After inoculation with CTV by single BrCA, the receptor indicator plants were grown in an insect-free greenhouse, and tested twice by ELISA with CTV MAb $17 \mathrm{G} 11$ in 4-6 months for the confirmation of CTV infections.

Collection and identification of aphids. Colonies of aphids collected from the citrus groves at Fort Pierce, Fla. were reared on virus-free citrus seedlings. Colonies were sampled, preserved in a mixture solution of 95\% ethanol and $75 \%$ lactic acid (2:1), and sent to the Division of Plant Industry Entomology Section, the Florida Dept. of Agriculture and Consumer Services, for identification of species (Banziger, 1977; Denmark, 1978). Those verified as Toxoptera citricida (BrCA) were later used to establish virusfree aphid colonies for CTV transmission experiments.

Establishment of virus-free aphid colonies. Single adult aphids of $\mathrm{BrCA}$ were transferred to a piece of filter paper in a plastic petri plate and were allowed to produce nymphs. The newborn nymphs were immediately moved onto young tender shoots of healthy 'Duncan' grapefruit seedlings. A colony of virus-free BrCA developed from each nymph after a few weeks. Colonies of virus-free $\mathrm{BrCA}$ were maintained on the 'Duncan' grapefruit seedlings until used. The healthy seedlings were cut back every two or three weeks to stimulate new flushes for the virus-free $\mathrm{BrCA}$. When the flushes of the rearing plants were getting old, the colonies of BrCA were moved to other uninfected plants with new flushes to maintain the reproduction of colonies.

Single aphid transmission. 'Duncan' grapefruit plants infected with the T-3, T-4, T-26, T-30, T-36, Y-3, Y-5, Y-6, Y-7, or MG-3 isolates of CTV were pruned several weeks before aphid acquisition feeding to stimulate flushes of new growth. When the new flushes had their leaves completely expanded, groups of 200-400 virus-free aphids were moved onto the new flushes for a $24-\mathrm{h}$ acquisition feeding. Single aphids were then transferred from 'Duncan' grapefruit using a small paintbrush to a new flush on healthy 'Mexican' lime seedlings.

Different treatments were made with different morphological stages (nymph, alatae, apterae) of the aphids. The aphids were allowed $24 \mathrm{~h}$ on the receptor seedlings for inoculation. After the inoculation feeding, pesticides (Marathon) or 1 soap : 1 oil : 30 water mixes were sprayed to kill the aphids. The inoculated 'Mexican' lime seedlings were kept under insect-free greenhouse conditions $\left(23\right.$ to $30^{\circ} \mathrm{C}$ ) for $4-6$ months. A total of 2120 healthy 'Mexican' lime seedlings were inoculated with 12 isolates of CTV by single $\mathrm{BrCA}$ in the experiment. The treatments were replicated over time. The transmission efficiency was defined as the ratio between the number of CTV-infected seedlings and the total number of aphid-inoculated seedlings.

Enzyme-linked immunosorbent assay (ELISA). Extractions for ELISA were prepared from $0.5 \mathrm{~g}$ of leaf tissues as described with $5 \mathrm{~mL}$ of $1 \times$ PBST buffer (Lin et al., 2000). Immulon 2 microtiter plates (Dynatech, Chantilly, Va.) were coated with rabbit polyclonal antibody 1212 at $1 \mu \mathrm{g} \cdot \mathrm{mL}^{-1}$ in $0.02 \mathrm{M}$ sodium carbonate buffer ( $\mathrm{pH}$ 9.6) and incubated overnight at $4{ }^{\circ} \mathrm{C}$. Then, the plates were washed with PBST-PVP (PBST with 2\% polyvinylpyrrolidone, $\mathrm{pH}$ 7.0) three times, 3 min each time. One hundred micro-liters of the sample extracts were added into each well of the plates. The plates were incubated for 4 $h$ at $37^{\circ} \mathrm{C}$, and washed with PBST-PVP three times as above. Again the plates were incubated with undiluted cell culture fluid of MAb 17G11 (a CTV specific MAb that reacts with most isolates of CTV) $(100 \mu \mathrm{L}$ each well) overnight at $4{ }^{\circ} \mathrm{C}$, and washed with PBST-PVP three times. The plates were then incubated with alkaline phosphatase conjugated goat anti-mouse Ig (H+L)-AP (South Biotechnology Associates, Birmingham, Ala.) $(100 \mu \mathrm{L}$ each well $)$ at a 1:2000 dilution in PBST-PVP for $4 \mathrm{~h}$ at $37{ }^{\circ} \mathrm{C}$ and washed with PBST-PVP three times. Substrate reactions $(1 \mathrm{mg} / \mathrm{mL} \rho$-nitrophenyl phosphate (Sigma, St. Louis) in $0.1 \mathrm{M}$ diethanolamine buffer, $\mathrm{pH}$ 9.8) were allowed to develop at room temperature, and absorbency values $(415 \mathrm{~nm})$ were determined using a Bio-Rad 3550 microtitre plate reader (Bio-Rad Laboratories, Richmond, Calif.).

Statistical analyses. Transmission rate (\%) data were subjected to an analysis of variance (ANOVA) by the SAS software program (SAS Inst., Cary, N.C.). Data were subjected to an arcsine square root transformation prior to conducting the ANOVA. Main effects were virus isolates and aphid morphology. A single degree of freedom contrast (Severe vs. mild isolates) was partitioned from the main effects of virus isolates. Since virus isolates $\times$ aphid morphology interaction was nonsignificant, only main effects were presented.

\section{Results}

Transmission efficiency of CTV from grapefruit by $\mathrm{BrCA}$. The transmission rates of CTV isolates from grapefruit seedlings to 'Mexican' lime seedlings by single BrCA were low (Table 1). The total infection rate by single $\mathrm{BCA}$ to 2120 receptor plants was $1.5 \%$.

Differences in transmission rates of different isolates of CTV. Four (T-36, Y-3, Y-6, and $\mathrm{Y}-7)$ of six severe isolates and three (T-4, T-26 and Y-23) of six mild isolates of CTV used in the experiments were transmitted by single BrCA (Table 1). Isolates T-3, MG-3, T-30, Y-5, and Y-26 were not transmitted by single BrCA. The transmission

Table 1. Differences in transmission efficiency of CTV isolates from grapefruit to Mexican lime by single $\mathrm{BrCA}$

\begin{tabular}{|c|c|c|c|c|}
\hline $\begin{array}{l}\text { CTV } \\
\text { isolate }\end{array}$ & $\begin{array}{l}\text { Isolate } \\
\text { source }^{z}\end{array}$ & Severity & $\begin{array}{c}\text { No. positive/ } \\
\text { no. inoculated }\end{array}$ & $\begin{array}{l}\text { Transmission } \\
\text { rate }(\%)^{x}\end{array}$ \\
\hline $\begin{array}{l}\mathrm{Y}-7 \\
\end{array}$ & $\mathrm{BD}$ & $\mathrm{S}$ & $4 / 110$ & 3.6 \\
\hline Y-6 & $\mathrm{BD}$ & $\mathrm{S}$ & $6 / 170$ & 3.5 \\
\hline Y-23 & $\mathrm{BD}$ & M & $3 / 100$ & 3.0 \\
\hline Y-3 & $\mathrm{BD}$ & $\mathrm{S}$ & $7 / 290$ & 2.4 \\
\hline T-36 & AT & $\mathrm{S}$ & $7 / 360$ & 2.0 \\
\hline $\mathrm{T}-4$ & AT & M & $2 / 100$ & 2.0 \\
\hline $\mathrm{T}-26$ & AT & M & $2 / 170$ & 1.2 \\
\hline T-30 & AT & M & $0 / 180$ & 0.0 \\
\hline T-3 & AT & $\mathrm{S}$ & $0 / 100$ & 0.0 \\
\hline MG-3 & $\mathrm{BD}$ & $\mathrm{S}$ & $0 / 310$ & 0.0 \\
\hline Y-5 & $\mathrm{BD}$ & M & $0 / 180$ & 0.0 \\
\hline Y-26 & $\mathrm{BD}$ & M & $0 / 50$ & 0.0 \\
\hline \multicolumn{5}{|c|}{ Contrast $^{\mathrm{w}}$} \\
\hline Seve & & & $24 / 1340$ & 1.8 \\
\hline Milc & & & 7/780 & 0.9 \\
\hline Total & & & $31 / 2120$ & 1.5 \\
\hline
\end{tabular}

${ }^{2} \mathrm{AT}=$ the isolates of CTV were obtained by aphid transmission from CTV-infected plants. $\mathrm{BD}=$ the isolates were obtained by budding (grafting) from CTV-infected plants.

${ }^{\mathrm{y}} \mathrm{S}=$ isolates that reacted with CTV specific monoclonal antibodies $17 \mathrm{G} 11$ and MCA13 and had a severe phenotype in indicators. $\mathrm{M}=$ isolates that reacted with CTV specific monoclonal antibodies 17G11 but not with MCA13 and had a mild phenotype in indicators. ${ }^{x} \mathrm{CTV}$ infection was determined by ELISA tests with CTV specific monoclonal antibody 17G11. The transmission rate of each isolate was a total transmission rate by a combination of all stages of BrCA used in the test. Differences among treatment means were significant at $P \leq 0.01$.

wThe transmission rates of severe or mild isolates were the total transmission rates by a combination of all stages of $\mathrm{BrCA}$ used in the test. The single degree of freedom contrast (severe vs. mild) was significant at $P \leq 0.05$. 
efficiency of severe isolates of CTV was higher than that of mild isolates of CTV (Table 1). The average transmission rate of six severe isolates of CTV was $1.8 \%$ while the average transmission rate of six mild isolates of CTV was $0.9 \%$. The highest transmission rate of a severe isolate was $3.6 \%$ from isolate $\mathrm{Y}-7$ and the highest transmission rate of a mild isolate was $3.0 \%$ from isolate Y-23 (Table 1). The CTV isolate $\times$ aphid morphology interaction was nonsignificant.

Effect of aphid morphological stages on transmission rate of CTV. The morphological stage, nymph, alatae and apterae, of the aphid may have affected the ability of BrCA to transmit CTV from grapefruit plants (Table $2)$. The transmission rates of CTV by alate adults and apterous adults of BrCA from grapefruit to 'Mexican' lime seedlings were not different (both were 1.5\%), but the transmission rate $(1.0 \%)$ of CTV by nymphs of BrCA from grapefruit seedlings to 'Mexican' lime seedlings was lower (Table 2).

\section{Discussion}

The results showed that BrCA is an inefficient vector of CTV when the source plant is grapefruit. Transmission rates from grapefruit by single BrCA were markedly lower than reported transmission rates from sweet orange and 'Mexican' lime. The transmission rates by single $\mathrm{BrCA}$ were $1 \%$ to $25 \%$ from sweet orange by Yokomi and Damsteegt (1990), $0 \%$ to $55 \%$ from sweet orange by Broadbent et al. (1996) and $16.6 \%$ to $66.6 \%$ from 'Mexican' lime by Nickel et al. (1984). In our hands, single BCA transmitted T36 and T30 from sweet orange to 'Mexican' lime with effectiveness of $8 \%$ and $5 \%$, respectively, based on $\approx 100$ attempts (Powell and Lin, unpublished). In experiments on CTV transmission with other aphids, BarJoseph et al. (1977) also pointed out that the transmission rate of CTV by aphids was influenced by the variety of citrus from which the virus was acquired. The transmission rate of CTV from grapefruit (C.paradisi) or lemon (C. limon) by the cotton aphid (Aphis gosypii) was much lower than that from other source plants. Taken together, these results suggested that the virus source plant markedly influenced the transmission efficiency of CTV and that grapefruit is not an efficient source plant of CTV for aphid transmission. The low efficiency may be associated with the distribution of CTV in grapefruit plants. Lee et al. (1988) reported that CTV was unevenly distributed in a grapefruit tree, especially in the

Table 2. Transmission efficiency of CTV from grapefruit to 'Mexican' lime within main effects of Morphological stages of BrCA.

\begin{tabular}{lcc}
\hline $\begin{array}{l}\text { Morphological } \\
\text { stage }\end{array}$ & $\begin{array}{c}\text { No. positive/ } \\
\text { no. inoculated }\end{array}$ & $\begin{array}{c}\text { Transmission } \\
\text { rate }(\%)\end{array}$ \\
\hline Apterae & $13 / 881$ & $1.5 \mathrm{a}^{z}$ \\
Alatae & $16 / 1037$ & $1.5 \mathrm{a}$ \\
Nymphs & $2 / 202$ & $1.0 \mathrm{~b}$
\end{tabular}

${ }^{2}$ Mean separation with a column by Duncan's multiple range test, $5 \%$ level. late summers. The relationship between the distribution of the virus in host plants and the transmission efficiency of the virus by vector aphids needs to be further studied. Since single BrCA transmits CTV inefficiently from grapefruit, large numbers of this aphid, $A$. gossypii and A. spiraecola are required for rapid spread of the virus in grapefruit groves. A. spiraecola with high populations were usually observed in citrus groves in Florida and California (Pelosi et al., 1996; Roistacher et al., 1980).

The results also indicate that there are differences in transmission efficiency of different isolates of CTV by single BrCA. The severe isolates were more easily transmitted than the mild isolates of CTV used in the experiment ( $1.8 \%$ and $0.9 \%$, respectively). This is in agreement with the previous results reported by Sharma (1989), Yokomi and Damsteegt (1990), and Broadbent et al. (1996). Their results disclosed that there were differences in transmission rates of different isolates of CTV from sweet orange or 'Mexican' lime plants by BrCA. They pointed out that $\mathrm{BrCA}$ may transmit severe isolates and severe latent-isolates of CTV efficiently. BarJoseph et al. (1977) also reported that the aphid transmission rates of CTV by cotton aphid also varied with the severity of CTV isolate.

The results showed that the morphological stage of BrCA might have an effect on its ability to transmit CTV. The ability of single adult of BrCA to transmit CTV from grapefruit to 'Mexican' lime was higher than that of BrCA nymphs. However, the ability of alatae and apterae of BrCA to transmit CTV from grapefruit to 'Mexican' lime were not different. These differences are not nearly as pronounced as those reported by Nickel et al. (1984). The transmission rates of CTV from 'Mexican' lime plants by alatae, apterae, and nymphs of BrCA reported by Nickel et al. (1984) were $66.6 \%, 25 \%$, and $16 \%$, respectively. The results reported by Costa et al. (1951) were different from that by Nickel et al. (1984) and our experiments. Their transmission rates of CTV from sweet orange by the single adults and nymphs of $\mathrm{BrCA}$ were $17 \%$ and $16 \%$, respectively, and the transmission rates of CTV from sweet orange by multiple adults and nymphs (25 aphid/plant) were $21 \%$ and $75 \%$, respectively. However, all results mentioned above indicate that the morphological stage of BrCA has apparent effects on its ability to transmit CTV. The apterae would be the most important for CTV movement under the natural conditions in the field.

\section{Literature Cited}

Abate, T. 1988. The identity and bionomics of insect vectors of tristeza and greening diseases of citrus in Ethiopia. Trop. Pest. Man. 34:1923.

Banziger, H. 1977. Keys to the identification of aphids (Homoptera). I. Winged aphids of species economically important in Thailand. F.A.O. Plant Prot. Bul. 36:2-41.

Bar-Joseph, M. and G. Loebenstein. 1973. Effects of strain, source plant, and temperature on the transmissibility of citrus tristeza virus by the melon aphid. Phytopathology 63:716-720.

Bar-Joseph, M., B. Raccah, and G. Loebenstein. 1977. Evaluation of the main variables that affect citrus tristeza virus transmission by aphids. Proc. of Intl. Soc. of Citricult. (3):958961.

Broadbent, P., R.H Brlansky, and J. Indsto. 1996. Biological characterization of Australian isolates of citrus tristeza virus and separation of subisolates by single aphid transmission. Plant Dis. 80:329-333.

Cambra, M., A. Hermoso de Mendozam, P. Moreno, and L. Navarro. 1981. Use of enzyme-linked immunosorbent assay (ELISA) for detection of citrus tristeza virus (CTV) in different aphid species. Proc. Intl. Soc. Citricult. (2):444-448.

Costa, A.S. and T.J. Grant. 1951. Studies on transmission of the tristeza virus by the vector Aphis citricidus. Phytopathology 16:105-133.

Costa, A.S., G.W. Multer, and C.L. Costa. 1968. Rearing the tristeza vector Toxoptera citricida on squash, p. 32-35 In: J.F.L. Childs (ed.). Proc. $4^{\text {th }}$ Conf. Intl. Organization of Citrus Virologists (IOCV). IOCV, Univ. of Florida Press, Gainesville.

Denmark, H.A. 1978. The brown citrus aphid, Toxoptera citricida (Kirkaldy) (Homoptera: Aphididae). Entomol. Circ. No. 194. Div. Plant Industry. Florida Dept. Agr. and Cons. Ser.

Essig, E.O. 1949. Aphids in relation to quick decline and tristeza of citrus. Pan. Pac. Entomol. 25:13-22.

Jackson L.K. 1991. Citrus growing in Florida (Third edition). Univ. of Florida Press, Gainesville.

Kano, T. and M. Koizumi. 1991. Separation of citrus tristeza virus (CTV) serotypes through aphid transmission, p. 82-85 In: P. Moreno, J.V. Da Graca, and L.W. Timmer (eds.). Proc. $12^{\text {th }}$ Conf. Intl. Organization of Citrus Virologists (IOCV). IOCV, Riverside, Calif.

Lastra, R., R. Lee, M.A. Rocha-Pena, C.L. Niblett, S.M. Garnsey, and R.K. Yokomi. 1992. Survey for presence of tristeza virus and Toxoptera citricidus in Mexico and Central America. Centro de Agricultura Tropical paro Investigation y Ensenonza-Univ. of Florida-Instituto nacional de Investigationes Forestales, Agricolas y Pecuarias/Scetrtaria de Agricultura y Recursos Hidraulicos-U.S. Dept. Agr., Turrialba, Costa Rica.

Lee. R.F., S.M. Gansey, L.J. Marais, and J.N. Moll. 1988. Distribution of citrus tristeza virus in grapefruit and sweet orange in Florida and South Africa, p. 33-38. In: L.W. Timmer, S.M Gansey, and L Navano (eds.). Proc. $10^{\text {th }}$ Conf. Intl. Organization of Citrus Virologists (IOCV). IOCV, Riverside, Calif.

Lin, Y., P.A. Rundell, L. Xie, and C.A. Powell. 2000. In situ immunoassay for detection of citrus tristeza virus. Plant Dis. 84:937-940.

Michand, J.P. 1998. A review of the literature on Toxoptera citricida (Kirkaldy) (Homoptera: Aphididae). Fla. Entomol. 81:37-61.

Nickel, O., F. Klingauf, and H. Fischer. 1984. Transmission of citrus tristeza virus (CTV) from "declinamiento"-diseased sweet orange tree on trifoliate orange and its epidemiology to the flight activity of the vector, Toxoptera citricida Kirkc (Homoptera: Aphididae) in Misioness, Argentina, p. 33-38. In: L.W Timmer, S.M Gansey, and L Navano (eds.). Proc. $10^{\text {th }}$ Conf. Intl. Organization of Citrus Virologists (IOCV). IOCV, Riverside, Calif.

Pelosi, R.R., E.E. Killer, and R.C. Bullock. 1996. Aphid populations in a Florida citrus tristeza virus suppression trial. Proc. Fla. State Hort. Soc. 109:69-72. 
Rocha-Pena M.A., R.F. Lee, R. Lastra, C.L. Niblett, F.M. Ochoa-Corona, S.M. Garnsey, and R.K. Yokomi. 1995. Citrus tristeza virus and its aphid vector Toxoptera citricida: Threats to citrus production in the Carbbean and Central and North America. Plant Dis. 79:437-445.

Roistacher, C.N. and M. Bar-Joseph. 1987. Aphid transmission of citrus tristeza virus: A review. Phytophylactica 19:163-167.

Roistacher, C.N., E.M. Nauer, A. Kishaba, and E.C. Calavan. 1980. Transmission of citrus tristeza virus by Aphis gossypii reflecting changes in virus transmission in California, $\mathrm{p}$. 76-82. In: E.C. Calavan, S.M. Garnsey, and L.W. Timmer (eds.). Proc. $8^{\text {th }}$ Conf. Intl. Orga- nization of Citrus Virologists (IOCV). IOCV, Riverside, Calif.

Sharma, S.R. 1989. Factors affecting vector transmission of citrus tristeza virus disease in South Africa.Zentralblatt fur Microbiologie 144:283294.

Yokomi, R.K. and V.D. Damsteegt. 1990. Comparison of citrus tristeza virus transmission efficiency between Toxoptera citricidus and Aphis gossypii, p. 319. In: Oklahoma State Univ. Agricultural Experiment Station (ed.). Proc. of aphid-plant interactions: Populations to molecules. Agr. Expt. Sta., Oklahoma State Univ. 132:319.

Yokomi, R.K., S.M., Garnsey, E.L. Civerolo, and
D.J. Gumpf. 1989. Transmission of exotic citrus tristeza virus isolates by a Florida colony. Plant Dis. 73:552-556.

Yokomi, R.K. and S.M. Garnsey. 1987. Transmission of citrus tristeza virus by Aphis gossypii and Aphis citricola in Florida. Phytophylactica 19:169-172.

Yokomi, R.K., R. Lastra, M.B. Stoetzel, V.D. Damsteegt, R.F. Lee, M.S. Garnsey, T.R. Gottwald, M.A. Rocha-Pena, and C.L. Niblett. 1994. Establishment of the brown citrus aphid (Homoptera: Aphididae) in Central America and the Caribbean Basin and transmission of citrus tristeza virus. J. Econ. Entomol. 87:10781085 . 